\title{
The Impacts of Ecosystem Hypertrophication and Climate Changes on Thrive of the Jellyfish in Shatt Al-Basrah Canal
}

\author{
Ali B. Mahmood ${ }^{1 *}$, Imad J. M. Al-Shawi², Hazem A. Al-Sayab ${ }^{1}$, Sejad K. Jasib¹, Zuhair A. \\ Abdulnabi $^{1}$, Nadia K. Muhsen ${ }^{1}$, Yosra J. Alewi ${ }^{1}$ \\ ${ }^{1}$ Marine Science Center, University of Basrah, Garmat Ali Campus, Al- Basrah, Iraq \\ ${ }^{2}$ College of Marine Sciences, University of Basrah, Garmat Ali Campus A, I- Basrah, Iraq \\ E mail: ali.baisel@uobasrah.edu.iq
}

\begin{abstract}
The present study (i.e. the first study in Iraqi waters) identified the causes of reproduction and excessive growth of the jellyfish, which locally known as thagolol, of the type (Catostylus perezi) in the region of Shatt Al-Basrah canal west of Basrah city. The reproduction and excessive growth of jellyfish occurs in many estuaries and coastal areas in the world, which is a recurring global problem in the context of climate change. The conducted study was included measurements of dissolved oxygen, electrical conductivity, total dissolved solids, $\mathrm{pH}$, temperature, nitrates, phosphate, quality and quantity of phytoplankton during the dominant of :the northwest winds; the neap tide and during a full tidal periods in October of 2018 and March of 2019. The results showed that there were thrive of jellyfish by huge numbers in Shatt Al-Basrah canal. The physical; chemical and biological causes (i.e., the local causes), were identified, namely: (1) salinity, (2) water column temperature stratification in the context of climate change, (3) an excessive increase in the concentrations of nitrate and phosphate, (4) abundance of phytoplankton (i.e. dinoflagellate), including Protoperidinium sp. and Alexandrium sp.; and (5) overfishing. Hence, the absence of any of these factors will lead to the absence of this type of jellyfish.
\end{abstract}

Keywords: Jellyfish, ecosystem hypertrophication, climate change, Shatt Al-Basrah canal.

\section{Introduction}

The preservation of the Iraqi marine environment and monitoring all changes that occur in conjunction with any human or natural causes within the challenges of climate changes was the motivation behind this research in Shatt Al-Basrah canal. The temperature is an important factor in controlling the abundance; distribution; propagation and growth of living organisms. The salinity is also very important in controlling the distribution and propagation of living organisms in this environment (Al- Shawi, 2010). The phytoplankton depends heavily on the light intensity in photosynthesis (Behrenfeld et al., 2002). On the other hand, each of: a scale of acidity values are between 7.5-8.4 in marine waters, where the low or high values cause damage to the growth and destruction of living organisms. The dissolved oxygen is an important factor for living organisms and its concentration reflects the state of the water surface (Mayza and Said, 1989). As well, the nutrients are an essential factor for the growth of phytoplankton in the study area (Al-Shawi, 2010), where the nitrogen is a dominant factor in the growth of phytoplankton ( $\mathrm{Li}$ et al., 2008). Moreover, the phosphate is also a dominant factor in the productivity of phytoplankton in shallow canals and lagoons (Dufour et al., 2001). While, the source of these nutrients is through the discharge of the northern part of the canal or the death and decomposition of living organisms or the discharge of the industrial facilities constructed on that canal in addition to the sewage and human waste of the Basrah city dumped in the stream of that canal. The narrow canals are good areas for increasing nutrient concentrations, particularly with high temperature and evaporation (Moran-Silva et al., 2005). There are several environmental studies (Al-Khayat, 2007; Al-Shawi, 2010; Amir and Ahmed, 2011), examined the physical and chemical properties of the waters of Shatt Al-Basrah canal. These studies included the total dissolved solids (TDS), electrical conductivity (EC), temperature (T), dissolved oxygen (DO), a scale of acidity $(\mathrm{pH})$ and nutrients; i.e. phosphate $\left(\mathrm{PO}_{4}\right)$ and nitrates ( $\left.\mathrm{NO}_{3}\right)$. All these studies confirmed that the water of the canal is not suitable for drinking or for agricultural purposes, and it is not suitable for the food industry or for the fish farming and reproduction. However, none of these studies and others includes the study of the reasons for the excessive growth and reproduction of jellyfish in the Shatt Al-Basrah canal. 
On the other hand, the nature Iraq organization was the first to record the first appearance of this type of jellyfish named (Catostylus perezi) in the north of the Shatt Al-Basrah canal in July of 2016 which was the first registration of this type in Iraq (Al-Obeidi, 2016), Figure 1 . This phenomenon is a global problem in the context of climate change, which has emerged in recent decades in many estuaries; coasts and open ocean ecosystems and it is repeated in many countries of the world (i.e., Britain; Cyprus; Lebanon; Spain; Egypt; Kuwait; the eastern coast of the United States and Japan). Figure 1, the first registration of the jellyfish (C. perezi) in the north of the Shatt AlBasrah canal in 2016 by the nature Iraq organization (Al-Obeidi, 2016).

The current study will determine the suitable conditions of the environment for the excessive growth and reproduction of the jellyfish and causes of the ecosystem hypertrophication. That is, identifying the main physical factors associated with climate change and causes this reproduction; also the chemical causes as well as indicate the importance of the phytoplankton in making this change in Shatt Al-Basrah canal, Figure 2. The significance of this study is to monitoring the effects of climate change.

The hypothesis of this study based on the following points: the sewage and other human waste of the Basrah city is one of the additional sources causing the increase in nutrient ratios in Shatt AlBasrah canal which will create an conducive environment to the thrive of phytoplankton-type dinoflagellate as well as the temperature and salinity are an important factors affecting the thrive of jellyfish in the context of climate change.

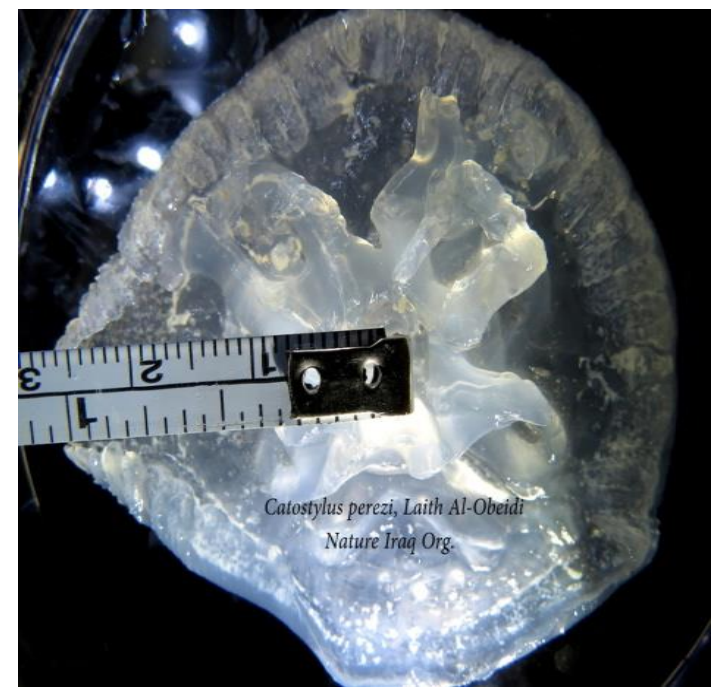

Figure 1. The first registration of the jellyfish (Catostylus perezi) in the north of the Shatt Al-Basrah canal in 2016 by the nature

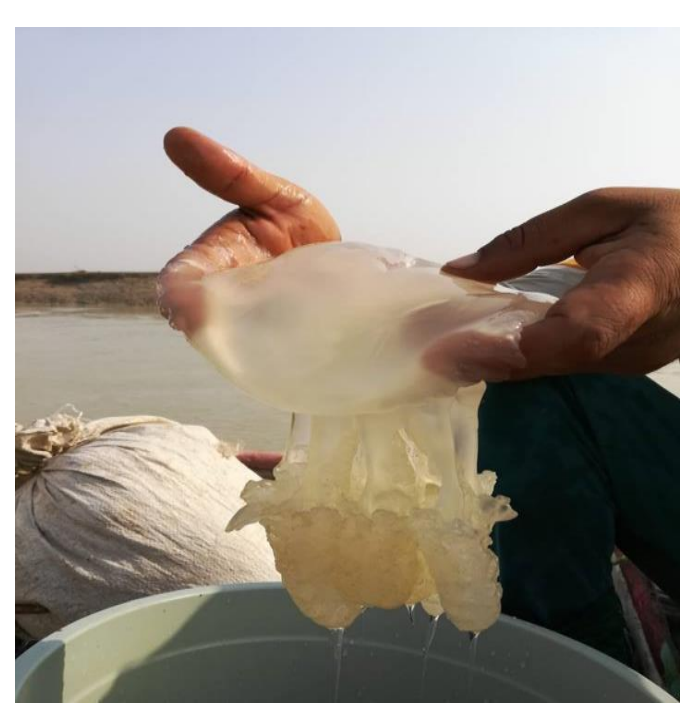

\section{Materials and Methods}

The Shatt Al-Basrah canal is located in the western part of the Basrah city and within the sedimentary plain between two latitudes (30'60'-

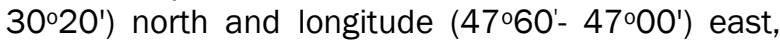
which extends for a length of $38 \mathrm{~km}$. The canal is part of the dry climatic zones that are characterized by length period of drought. It is one of the important canals and its environment includes many organisms. This canal is located under the influence of the tidal system in the north of Khor Al-Zuber. It is a mixed tidal system, which is dominated by a semidiurnal tidal wave (i.e., two high tides and two low tides in one day with varying in amplitudes due to the length of the low tide in comparison with the length of the high tide). The discharge rate of the Shatt Al-Basrah canal is about $325 \mathrm{~m}^{3} \cdot \mathrm{sec}^{-1}$ during the period of the high tide and $1050 \mathrm{~m}^{3} \cdot \mathrm{sec}^{-1}$ during the period of the low tide. The tidal water also is the most important source of water in this canal (AlKhayat, 2007; Amir and Ahmed, 2011).

\section{Fieldwork and data analysis}

The study station was selected at the following geographical position (30 030.3'55.1 "N 47082.6'38.1" E), which is located at the confluence of Shatt Al-Basrah canal with Khor Al-Zuber, Figure 2. In order to study the influence of human waste, it was necessary to choose the most sensitive and most important region which is the confluence of Shatt Al-Basrah with Khor Al-Zuber. As this region there is continuous mixing happened between the water of the canal with the water of the Khor AlZuber, where this region is under the influence of the phenomenon of tides. In addition, the confluence

\footnotetext{
Iraq organization (Al-Obeidi, 2016).
} 


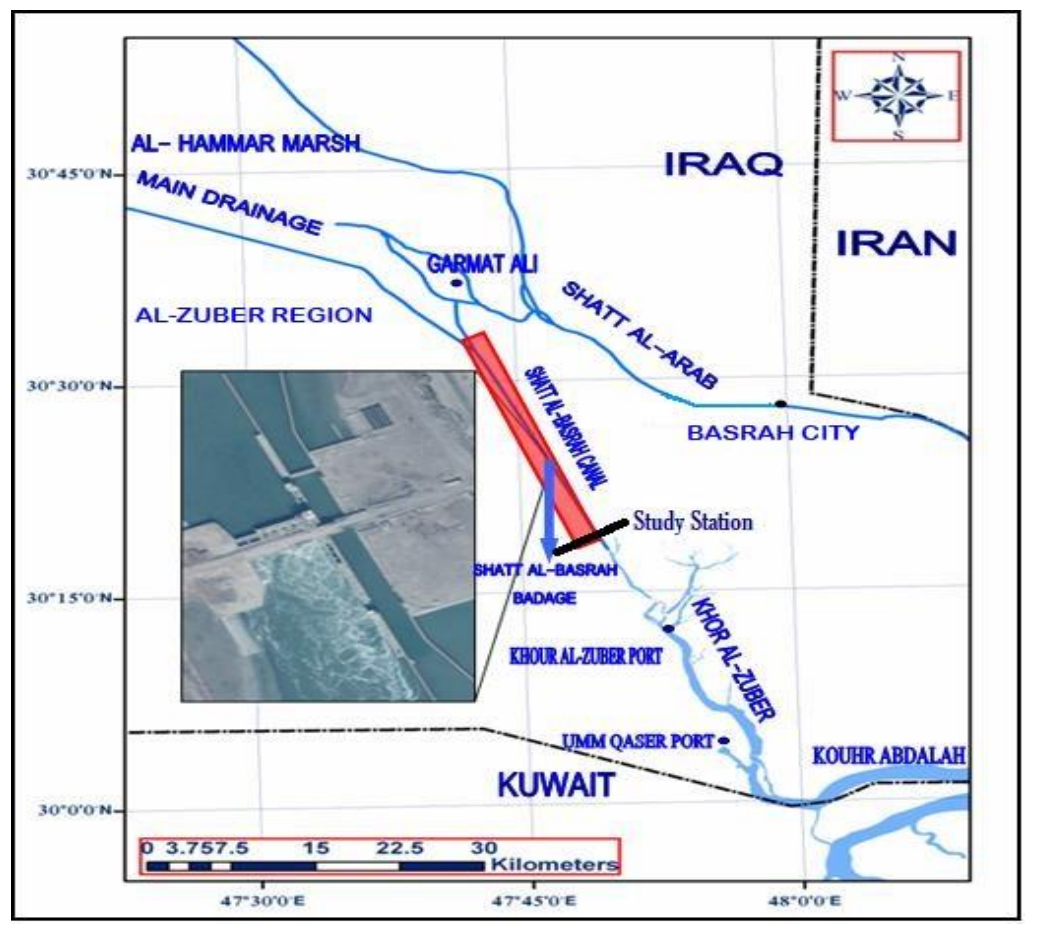

Figure 2. Schematic of Shatt Al-Basrah canal and study station at the west of Basrah city (MSC, 2016)

zone has significant variations in temperature; salinity; water density and quality, making it a conducive environment to the growth and reproduction of jellyfish in huge numbers.

The width of the river was about 100 meters and about 10 meters deep in the study station. The prevailing tide type during the measurement period was the neap tide and the prevailing wind was the North West and its magnitude was about 3-11 km.h1. The average or air temperature was between 15 $26^{\circ} \mathrm{C}$ during the days $17 / 10 / 2018$ and $4 / 3 / 2019$ respectively.

Practically, the values of temperature; electrical conductivity; total dissolved solids; $\mathrm{pH}$ and dissolved oxygen at the surface and bottom have been measured for a full tide period during the measurement days. The water samples were collected to determine nitrate concentrations $\left(\mathrm{NO}_{3}\right)$ and phosphate $\left(\mathrm{PO}_{4}\right)$ from a surface; mid and bottom during the measurement days within a full tide period using plastic bottles (5 liters). The samples were tested using the chloroform solution to be analyzed in the laboratory and then filtered using the filter papers with a diameter of $0.45 \mu \mathrm{m}$ and then should be frozen until the date of exam. A boat was used for the field work and the sampling was done during the periods of low tide and high tide (i.e. ebb and flood respectively) were determined using the tidal tables issued by the General Company of Iraqi Ports for the years 2018 and
2019. The CRISON Multimeter device was used for field measurements.

The phytoplankton samples were collected using a 20 micron mesh, where the collection process was carried out by dragging the mesh onto the surface of the water during the boat trip. The samples were then placed in plastic bottles $(5 \mathrm{~L})$ after being installed in the field with a Logal solution that was prepared according to the method described in Lind (1979). The samples were well washed and concentrated using the centrifuge. The phytoplankton species were then identified using the following references: Husted (1930; 1985); CleveEuler (1951-1955); Hendey (1964; 1970); Dodge (1982); Dodge (1985); Snoeijs (1993); Snoeijs and Vilbaste (1994); Snoeijs and Potapova (1995); Snoeijs and Kasperoveiciene (1996); Snoeijs and Balashova (1998); Botes (2001) and Perry (2003).

\section{Results and Discussion}

The selection of the sampling study station at the confluence of Shatt Al-Basrah canal with Khor AlZuber is a good location to monitor the changes taking place in the ecosystem as well as to monitor the effects of climate change as a site or a system that maintains balance between Shatt Al-Basrah and Khor Al-Zuber. Therefore, it is possible to sense and identify the causes of the ecosystem hypertrophication, as well as climatic causes and 
other that caused by human interventions or natural causes.

The results in Table 1 show that $\mathrm{pH}$ values vary widely (5.98-8.2 and 8.06-8.87). As, when compared with the values of the Iraqi specifications (Amir and Ahmed, 2011), it will be less than the allowed limit so it is good quality waters as far as the matter of $\mathrm{pH}$. The values of $\mathrm{pH}$ fluctuate significantly during the day in the canal due to the impact of the phenomenon of tides and the mixing of waters (AlZubaidi, 1985). The increase in $\mathrm{pH}$ is due to the abundance of phytoplankton, which causes a decrease in the values of carbon dioxide in water as a result of depletion in the process of photosynthesis (Amir and Ahmed, 2011).

Table 1. Field measurements for pH, EC, TDS, T, DO, NO3, and PO4 in the cases of low tide and high tide at the study station. The values between the brackets on the right represent the measurements in the first day $17 \backslash 10 \backslash 2018$, while, the values on the left are the measurements in the second day $4 \backslash 3 \backslash 2019$.

\begin{tabular}{|c|c|c|c|c|c|c|}
\hline \multirow{2}{*}{$\begin{array}{c}\text { Low tide } \\
\text { Depth }\end{array}$} & \multirow[b]{2}{*}{ Time (h.min.) } & \multirow[b]{2}{*}{$\mathrm{pH}$} & \multirow[b]{2}{*}{$\begin{array}{c}\text { EC } \\
\left(\mathrm{mmho}^{\left.-\mathrm{cm}^{-1}\right)}\right.\end{array}$} & \multirow[b]{2}{*}{ TDS (ppt) } & \multirow[b]{2}{*}{$\mathrm{T}\left({ }^{\circ} \mathrm{C}\right)$} & \multirow[b]{2}{*}{ DO (mg. $\left.\mathrm{L}^{-1}\right)$} \\
\hline & & & & & & \\
\hline Surface & 8.25 & $(8.87),(5.98)$ & $(8.02),(72.8)$ & $(46.4)), 32.2($ & $(15.6),(26.9)$ & (43.9),(5.02) \\
\hline Bottom & 8.25 & $(8.84),(6.06)$ & $(72)), 6.5($ & $(26.1),(46)$ & (15),(26.4) & $(44.5),(5.11)$ \\
\hline Surface & 9.25 & $(8.7),(6.6)$ & $(8.5),(72.7)$ & $(34.3),(46.5)$ & $(16.4),(26.3)$ & $(40.3),(5.1)$ \\
\hline Bottom & 9.25 & (8.8),(7.1) & $72)),(7.3($ & $(29.6),(46)$ & $(15.6),(26)$ & $(40.9),(5.2)$ \\
\hline Surface & 10.25 & $(7.6)(8.6)$ & $(5.7),(72.7)$ & (23.1),(46) & $(16.7),(26.8)$ & (29.1),(4.9) \\
\hline Bottom & 10.25 & $(7.8)(8.5)$ & $(5.5),(72)$ & $(22.2),(46)$ & $(16.0),(26.3)$ & $(30.2),(5.1)$ \\
\hline Surface & 11.25 & $(7.9)(8.5)$ & $(3.9),(72.5)$ & $(15.66),(46.4)$ & $(16.9),(27.7)$ & $(26.2),(4.6)$ \\
\hline Bottom & 11.25 & $(8.1)(8.5)$ & (3.8),(71.9) & $(14.2),(46)$ & $(16.2),(26.8)$ & $(26.4),(4.7)$ \\
\hline Surface & 12.25 & $(8.5),(8.1)$ & $(3.7),(72.1)$ & $(13.9),(46.1)$ & $(17.3),(27.3)$ & $(24.9),(4.6)$ \\
\hline Bottom & 12.25 & $(8.1)(8.5)$ & $(4.0),(72)$ & $(13.8),(46)$ & $(16.7),(27)$ & (25.9),(4.9) \\
\hline \multicolumn{7}{|l|}{ High tide } \\
\hline Depth & Time (h.min.) & $\mathrm{pH}$ & $\begin{array}{c}\text { EC } \\
\left(\mathrm{mmho}^{\left.-\mathrm{cm}^{-1}\right)}\right.\end{array}$ & TDS (ppt) & $\mathrm{T}\left({ }^{\circ} \mathrm{C}\right)$ & DO (mg. L-1) \\
\hline Surface & 1.25 & $(8.11),(8.2)$ & $(4.54),(71.9)$ & $(18.22),(46)$ & $(18.4),(28.2)$ & (20.9),(4.5) \\
\hline Bottom & 1.25 & $(8.06),(8.2)$ & $(4.57),(71.8)$ & $(18.32),(45.9)$ & $(17.8),(27)$ & (23.9),(4.9) \\
\hline Surface & 2.25 & $(8.5),(8.2)$ & $(4.64),(72)$ & (18.59),(46.1) & $(18.4),(28.5)$ & $(24.8),(4.5)$ \\
\hline Bottom & 2.25 & $(8.37),(8.1)$ & $(4.66),(72)$ & (18.68),(46.1) & $(17.0),(27.8)$ & $(27.9),(4.8)$ \\
\hline Surface & 3.25 & $(8.6),(8.2)$ & $(4.67),(72)$ & $(18.71),(46)$ & $(17.6),(28.1)$ & $(25.4),(4.8)$ \\
\hline Bottom & 3.25 & $(8.83),(8.2)$ & $(4.65),(72.4)$ & $(18.66),(46.3)$ & $(16.8),(26.9)$ & $(25.8),(5.2)$ \\
\hline Surface & 4.25 & $(8.6),(8.2)$ & $(4.66),(72.4)$ & $(18.5),(46.3)$ & $(17.4),(27.8)$ & (25.1),(5.3) \\
\hline Bottom & 4.25 & $(8.8),(8.2)$ & $(4.64),(72.5)$ & $(18.6),(46.4)$ & $(16.7),(26.3)$ & $(25.2),(5.5)$ \\
\hline Surface & 5.25 & $(8.4),(8.2)$ & $(4.62),(72)$ & $(18.4),(46)$ & $(17.0),(26.9)$ & $(25.1),(5.4)$ \\
\hline Bottom & 5.25 & $(8.3),(8.2)$ & $(4.67),(72.4)$ & $(18.7),(46.2)$ & $(15.8),(25.7)$ & $(25.3),(5.6)$ \\
\hline \multicolumn{7}{|l|}{ Low tide } \\
\hline Depth & Time (h.min.) & $\mathrm{NO}_{3}$ (mg.nitr & sen atom. $\left.L^{-1}\right)$ & Depth & Time (h.min.) & $\mathrm{NO}_{3}$ (mg.nitrogen atom. $\mathrm{L}^{-1}$ ) \\
\hline Surface & 9.25 & $(2.624542$ & $(0.005193)$ & Surface & 10.25 & $(2.562852),(0.00452)$ \\
\hline Mid & 9.25 & $(2.872842$ & $(0.003 .85)$ & Mid & 10.25 & $(3.470211),(0.00598)$ \\
\hline Bottom & 9.25 & $(2.658486$ & $0.00375)$ & Bottom & 10.25 & $(0.01201),(2.765664)$ \\
\hline \multicolumn{7}{|l|}{ High tide } \\
\hline Depth & Time (h.min.) & $\mathrm{NO}_{3}$ (mg.nitr & sen atom. $\left.L^{-1}\right)$ & Depth & Time (h.min.) & $\mathrm{NO}_{3}$ (mg.nitrogen atom. $\mathrm{L}^{-1}$ ) \\
\hline Surface & 3.25 & (3.162558 & $(0.00947)$ & Surface & 4.25 & $(2.939457),(0.004400)$ \\
\hline Mid & 3.25 & $(2.733007$ & $(0.00623)$ & Mid & 4.25 & $(2.81798),(0.00698)$ \\
\hline Bottom & 3.25 & (3.097663 & $(0.00486)$ & Bottom & 4.25 & $(2.913838),(0.0126)$ \\
\hline \multicolumn{7}{|l|}{ Low tide } \\
\hline Depth & Time (h.min.) & $\mathrm{PO}_{4}$ (mg.phos & hor atom. $L^{-1}$ ) & Depth & Time (h.min.) & $\mathrm{PO}_{4}$ (mg.phosphor atom. $\left.\mathrm{L}^{-1}\right)$ \\
\hline Surface & 9.25 & $(0.11)$ & $.0058)$ & Surface & 10.25 & $(0.0154),(0.124)$ \\
\hline Mid & 9.25 & $(0.035)$ & $0.0043)$ & Mid & 10.25 & $(0.05),(0.04)$ \\
\hline Bottom & 9.25 & $(0.089)$ & $0.0173)$ & Bottom & 10.25 & $(0.087),(0.0096)$ \\
\hline \multicolumn{7}{|l|}{ High tide } \\
\hline Depth & Time (h.min.) & $\mathrm{PO}_{4}$ (mg.phos & hor atom. L-1) & Depth & Time (h.min.) & $\mathrm{PO}_{4}$ (mg.phosphor atom. $\mathrm{L}^{-1}$ ) \\
\hline Surface & 3.25 & $(0.053)$ & $0.0038)$ & Surface & 4.25 & \\
\hline Mid & 3.25 & $(0.108)$ & $0.0037)$ & Mid & 4.25 & $(0.131),(0.03)$ \\
\hline Bottom & 3.25 & $(0.071)$ & $0.0038)$ & Bottom & 4.25 & $(0.101),(0.0173)$ \\
\hline
\end{tabular}


On the other hand, the difference in the quality of discharges into the canal stream within the one day may cause this variation in $\mathrm{pH}$ values. As shown by the results, $\mathrm{pH}$ values in the low tide period change from their acidic to alkaline values in the final hours of that period (i.e. within the measurements of the first day). Whereas, comparing the results of the dissolved oxygen, see Table 1, with its values within the Iraqi specifications (Amir and Ahmed, 2011), we found it exceeded the allowed limit. So the canal water is not suitable for drinking. The increase in dissolved oxygen values is due to increased solubility; low consumption; increased water speed and mixing activity at the study region (Al-Lami, 1986). The results (in the cases of low and high tides) show that the dissolved oxygen values have a lower value in the surface layer than in the deep layer and are associated with the intense evaporation at the surface. The total values of the dissolved solids, see Table 1 , are higher than the permitted levels within the Iraqi standard. Therefore, the water in Shatt Al-Basrah canal is not suitable for drinking. The values of the total dissolved solids fluctuate according to the temperature and evaporation under the influence of the tide phenomenon, which is inversely proportional to the fresh water discharges (Al-Khayat, 2007). The increase in the values of the total dissolved solids is due to following factors: the abundance of discharge of sewage of Basrah city; the Paracentesis and the industrial waters dumped in the stream of the canal under the influence of the phenomenon of tides; the increasing of temperature and evaporation rates; the poor rainfall and reduced freshwater discharges coming from the northern area of the canal. The results in Table 1 show that the values of the electrical conductivity have been shown to be high in comparison with the study of Al-Shawi (2010) in both cases of the tides during the first day of measurements due to the poor rainfall and reduced discharge of fresh water coming from the north of AlBasrah canal. The results also showed equal values between the surface and the bottom of both of the electrical conductivity and the values of the total dissolved solids in the two cases of tides. The reason is the effect of mixing and circulation processes under the influence of the phenomenon of tides. While the measurements of the second day showed that the values of the electrical conductivity and the total dissolved solids decreased significantly due to the increase of excessive rainfall during the winter of 2019 and the increase in freshwater discharges coming from the northern canal, which caused this decline. Moreover, the values of conductivity and total dissolved solids showed that there was a direct relationship between them in both days of measurements. On the other hand, each of the values of nitrates and phosphate have shown a significant increase in the first day of measurements in comparison with the Iraqi standard (Amir and Ahmed, 2011), which is due to the increase of sewage discharge of Basrah city as one of the sources of waters in the canal that increasingly excessive.

In addition, the measurements of the second day showed higher values than the permitted rates in comparison with the Iraqi standard (Amir and Ahmed, 2011), hence, the water canal is not suitable for drinking. On the other hand, the increase of recent concentrations cause an increase in the growth of algae, which has been reflected in the excessive growth and reproduction of phytoplankton species of dinoflagellate and thus increase the thrive and reproduction of jellyfish in the canal of Shatt AlBasrah. In terms of the second day, the values of dissolved oxygen, see Table 1, are higher than the permissible limit of the Iraqi standard for living and breeding fish. Similarly, when comparing the total values of dissolved solids with their values in the Iraqi standard, they are higher than the permissible limit, so the water of the canal is not suitable for agricultural use or for use in the food industry. The results of the water temperature in the first day of measurements showed that the stratification was found in water column temperature, see (Figure 3 ) in the context of climate change, where, the temperature during the high tide was higher than the low tide according to the effects of solar radiation.

Moreover, the increase in nitrate and phosphate levels are clear as shown in Table 1, which cause the excessive reproduction of the jellyfish in the canal. Thus, the temperature stratification; mixing process under the influence of the phenomenon of tides; winds and so on with the increase of nutrient concentrations have created a suitable environment for the migration of phytoplankton species of dinoflagellate to the bottom layer, which caused this thrive and reproduction of jellyfish.

The results in Table 2 indicated the recording of a number of phytoplankton species belonging to the Mastigophora (i.e. dinoflagellate) and diatoms as well as the presence of small zooplankton species. The predominance was evident for various types of dinoflagellate including Alexandrium sp. and Protoperidinium sp. by numbers of up to 24000 cells. $\mathrm{L}^{-1}$, which contributed to increase the toxicity of waters in the Shatt Al-Basrah canal. As, the results have been showed clear presence of important types of diatoms, including a type of Melosira sp.

It has become clear from the field observations that jellyfish enter the waters of Khor Al-Zuber and to the canal of Shatt Al-Basrah during the tide period with the entry of large numbers of phytoplankton searching of food as recorded 


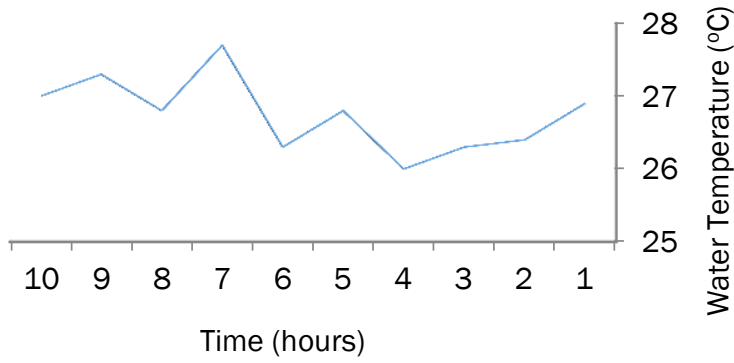

Low Tide

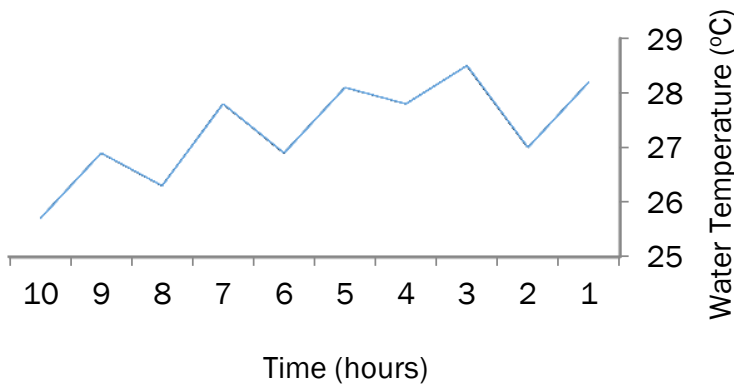

High Tide

Figure 3. The stratification in the water column temperature in the context of climate changes for the first day of measurements. The crest is the surface temperature. The trough is the bottom temperature as a function of the low and high tides during a full tide cycle.

especially the dinoflagellate. Field observations have also shown that jellyfish settle in the bottom of the canal during the period of low tide where the appropriate temperatures and food availability. In addition, the abundance of a specific type of phytoplankton from dinoflagellate, Table 2, will make the competition between fish (if found) and jellyfish very similar to plankton species, and with the excessive fishing of these fish, this will allow more time to grow and reproduction of jellyfish. As for the measurements of the second day, Table 1, due to the low values of electrical conductivity and the total dissolved solids,

Table 2. Shows the most important phytoplankton and zooplankton species recorded in the study area

\begin{tabular}{|c|c|}
\hline Species & Occurrence \\
\hline Actinocyclus & ++ \\
\hline Campylodiscus sp. & ++ \\
\hline Coscinodiscus sp. & ++ \\
\hline Chaetoceros sp. & + \\
\hline Eucampia sp. & + \\
\hline Gyrosigma & ++ \\
\hline Melosira sp. & +++ \\
\hline Nitzschia sp. & + \\
\hline Rhizosolina sp & ++ \\
\hline Skeletonema & + \\
\hline Surirlla gemma Her. & ++ \\
\hline Alexandrium & +++ \\
\hline Ceratium & ++ \\
\hline Dinophysis & + \\
\hline Prorocentrum & ++ \\
\hline Protoperidinium sp. & +++ \\
\hline Copepod (Nupliar Stages) & ++ \\
\hline Rotifera & ++ \\
\hline Tintinnida & +++ \\
\hline
\end{tabular}

this indicates to the fact that the water of the canal is of the type of brackish water, which is the intermediate stage between the fresh and marine water. Therefore, that cause the absence of jellyfish in the canal despite abundance nitrate and phosphate concentrations; excessive phytoplankton and temperate temperature in the water column. The degree of marine salinity is one of the most effective factors affecting the life and abundance of jellyfish. In addition, the continuous monitoring by the fishermen of the jellyfish in the Shatt Al-Basrah canal confirms that it appearance was confined between June and July in 2016 and usually disappears in the middle of the August. In 2018, the jellyfish appeared in the middle of the March and expected to be disappeared in the middle of the August.

\section{Conclusions}

Canal water is not currently suitable for human use (i.e., drinking purposes); for agriculture purposes or for food industry purposes. Canal water is not suitable for living and reproduction of fish. The increase of nitrates and phosphate concurrent with the increasing discharge of sewage, human waste and other human contributions of the Basrah city in the stream of the canal caused the growth and reproduction of phytoplankton, which enabled the dinoflagellate to growth to be dominance, which caused excessive reproduction in the numbers of jellyfish. The abundance of a specific species of phytoplankton and the overfishing of fish will work towards the excessive growth and reproduction of jellyfish. Increasing the water temperature than the natural levels caused the abundance of different types of phytoplankton. The stratification in the water column temperature coincided with the 
changes in climate caused the migration of dinoflagellate during the water column to the depths leading to the dominance of the Protoperidinium sp. And Alexandrium and hence increase the reproduction of the jellyfish. Thus, the thrive of the phytoplankton will be contributed to increase the toxicity of water in the Shatt Al-Basrah canal and this is the effects of climate change. Increasing the values of electrical conductivity and total dissolved solids caused the presence of jellyfish in the Shatt Al- Basrah canal. The physical; chemical and biological causes (i.e., local causes) leading to the thrive of jellyfish in the Shatt Al-Basrah canal were identified, namely: marine salinity, water column temperature stratification in the context of climate change, an excessive increase in the concentrations of nitrate and phosphate, abundance of phytoplankton (i.e. dinoflagellate), including Protoperidinium sp. and Alexandrium.

\section{References}

Al-Khayat, N.M. 2007. The hydrological situation of the Shatt al-Basrah Canal and some of its environmental effects. J. of the Arts of Basrah 43: 214-229.

Al-Zubaidi, A.J.M. 1985. Environmental studies on algae and phytoplankton in some areas of the marshes near Qurna in southern Iraq. Master thesis, unpublished, Basrah University.

Al-Shawi, E.J. 2010. Environmental and phytochemical study of phytoplankton in Khor al - Zubayr with total levels of hydrocarbons. PhD thesis, University of Basrah.Basrah. 165 pp.

Amir, A.S. \& Ahmed, M. 2011. Channel Shatt al-Arab: a field study. J. of Basrah Studies, 7(12): 288331.

Al-Lami, A.A.Z. 1986. Environmental study on phytoplankton of some marshes in southern Iraq. MsC thesis, University of Basrah, Basrah.

Al-Obeidi, L.A. 2016. First record of Jellyfish (Catostylus perezi). Available at: http://www. natureiraq.org/news/first-record-of-jellyfishcatostylus-perezi-for-iraq. Accessed: 19 October 2018.

Behrenfeld, M.J., Maranon, E., Siegel, D.A. \& Hooker, S.B. 2002. Photoacclimat -ion and nutrientbase model of light-Saturated photosynthesis for quantifying ocean primary production. Mar. Ecol. Prog. Ser. 228: 103-117
Botes, L. 2001. Phytoplankton identification catalogue. Saldanha bay, South Africa. GloBallast Monograph Series No.7, 88pp.

Cleve-Euler, A. 1951. Die Diatomeen von Schwenden und Finnland. K. Svensh. Akad. Handl. 4, 2(1):1-163.

Cleve-Euler, A. 1952. Die Diatomeen von Schwenden und Finnland. K. Svensh. Akad. Handl. 3(3):1153.

Cleve-Euler, A. 1953. Die Diatomeen von Schwenden und Finnland. K. Svensh. Akad. Handl. 4(1):1158 .

Cleve-Euler, A. 1954. Die Diatomeen von Schwenden und Finnland. K. Svensh. Akad. Handl. 4(5):1225

Cleve-Euler, A. 1955. Die Diatomeen von Schwenden und Finnland. K. Svensh. Akad. Handl. 5(4):1232.

Dodge, J.D. 1982. Marine dinoflagellate of the British Isles. H.M.S.O. London, 303p.

Dodge, J.D. 1985. Atlas of dinoflagellates. A Scanning Electron Microscope Survey. Farrand Press, London, $119 \mathrm{pp}$.

Dufour, P., Andréfouët, S., Charpy, L. \& Garcia, N., 2001. Atoll morphometry controls lagoon nutrient regime. Limnology and Oceanography, 46(2): 456-461. https://doi.org/10.4319/lo. 2001.46.2.0456

Hendey, N.I. 1964. An introduction account of smaller algae of British coastal water. V. Bacillatriophyceae. H. M. Stationary Office, London.

Hendy, N.I. 1970. Some littoral diatoms of Kuwait. Nova Hedwigia, 31:1-107.

Husted, F. 1930. Die kieselagen deutschlans, osterreichs und der schweiz mit beruchsicntigung der ubrigen lander europas in sowie der angrenzendern meeresgebiet. Kryptogamen-flora 7(1):1-920.

Husted, F. 1985. The Pennate Diatoms.Koeltz Scientific Book. Koenigstein, Sweden, 918 pp.

Li, Q.P., Dennis, H.A. \& Zhang, J.Z. 2008. Underway monitoring of nanmolar nitrate plus nitrite and phosphate in oligotrophic seawater. Limnol. Oceanogr. 6:319-326. doi: 10.4319/lom. 2008.6.319. 
Lind, O.T. 1979. Hand book of common methods in limnology. 2nd. Ed. London 109 pp.

Mayza , A.L. \& Said, A.M. 1989. The time variation and temperature, salinity and oxygen content in the east Harbor of Alexandria. Bull. Inst. Oceanogr. Fish. 15(2): 39-45.

Moran-Silva, A., Franco, L.A.M., Chavez-Lopez, R., Franco-Lopez, J., Bedia, S., Espinosa, F.C., Mendicta, F.G., Brown, P.N. \& Peterson, M.S. 2005. Seasonal and spatial pattern in salinity, nutrients and chlorophyll a in the Alvarado lagoon system. Veracruz, Mexico. Gulf and Caribbean Res. 17:133-143.

MSC-Marine Science Center 2016. Monthly data measurements. Tech. Rep., Univ. of Basrah, 77 pp.

Perry, R.A. 2003. A guide to the marine plankton of south Californian.3rd Edition Report by UCLA ocean-globe and High School. 23pp.

Snoeijs, P. 1993. Intercalibration and distribution of diatom species in the Baltic Sea. The Baltic
Marine Biologists. Opulus Press Uppsala. Publication No. 16a, pp 1-129

Snoeijs, P. \& Balashova, N. 1998. Intercalibration and distribution of diatom species in the Baltic Sea. The Baltic Marine Biologists. Opulus Press Uppsala. Publication No. 16e, 143 pp.

Snoeijs, P. \& Kasperoveiciene, J. 1996. Intercalibration and distribution of diatom species in the Baltic Sea. The Baltic Marine Biologists. Opulus Press Uppsala. Publication No.16d, 125 pp.

Snoeijs, P. \& Potapova, M. 1995. Intercalibration and distribution of diatom species in the Baltic Sea. The Baltic Marine Biologists. Opulus Press Uppsala. Publication No.16c, 125 pp.

Snoeijs, P. \& Vilbaste, S. 1994. Intercalibration and distribution of diatom species in the Baltic Sea. The Baltic Marine Biologists. Opulus Press Uppsala. Publication No. 16b, 125 pp. 